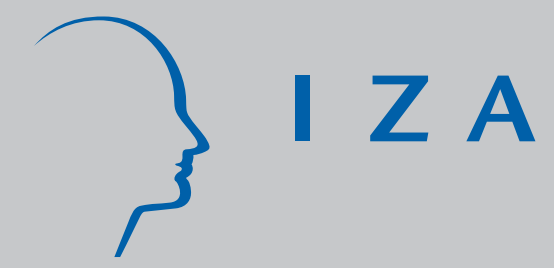

IZA DP No. 2097

Wage Inequality and J ob Insecurity among Permanent and Contract Workers in India: Evidence from Organized Manufacturing Industries

Amit K. Bhandari

Almas Heshmati

April 2006 


\title{
Wage Inequality and Job Insecurity among Permanent and Contract Workers in India: Evidence from Organized Manufacturing Industries
}

\author{
Amit K. Bhandari \\ University of Kalyani \\ Almas Heshmati \\ TEPP, Seoul National University, \\ Ratio Institute and IZA Bonn
}

Discussion Paper No. 2097

April 2006

IZA
P.O. Box 7240
53072 Bonn
Germany

Phone: +49-228-3894-0

Fax: +49-228-3894-180

Email: iza@iza.org

\begin{abstract}
Any opinions expressed here are those of the author(s) and not those of the institute. Research disseminated by IZA may include views on policy, but the institute itself takes no institutional policy positions.

The Institute for the Study of Labor (IZA) in Bonn is a local and virtual international research center and a place of communication between science, politics and business. IZA is an independent nonprofit company supported by Deutsche Post World Net. The center is associated with the University of Bonn and offers a stimulating research environment through its research networks, research support, and visitors and doctoral programs. IZA engages in (i) original and internationally competitive research in all fields of labor economics, (ii) development of policy concepts, and (iii) dissemination of research results and concepts to the interested public.
\end{abstract}

IZA Discussion Papers often represent preliminary work and are circulated to encourage discussion. Citation of such a paper should account for its provisional character. A revised version may be available directly from the author. 


\title{
ABSTRACT
}

\section{Wage Inequality and Job Insecurity among Permanent and Contract Workers in India: Evidence from Organized Manufacturing Industries*}

\begin{abstract}
Since the early 1990s, the employment structure of organised manufacturing industries in India has undergone substantial changes with the steep rise in the use of contract workers in place of permanent workers. This process has led to increased wage inequality, discrimination as well as the concern of job insecurity in the labour market. We focus on the wage inequality between permanent and contract workers, since contract workers earn substantially lower wages than their counterpart. The study uses data at the individual level from a recent labour survey of organised manufacturing industries in India. The lower wage earned by contract worker is largely due to cost cutting, rather than differences in labour productivity. The issue of job insecurity has been modeled in form of a binary logistic model. The factors affecting job security are divided as productivity related attributes like level of education, skill etc. and institutional attributes such as labour market rules and regulations, union membership etc. Contrary to the general expectation the study finds that permanent workers are more concern of job insecurity than contract workers.
\end{abstract}

JEL Classification: $\quad \mathrm{J} 70, \mathrm{~J} 31, \mathrm{~J} 60$

Keywords: job security, discrimination, wages, decomposition, permanent and contract workers, manufacturing

Corresponding author:

Almas Heshmati

Techno-Economics \& Policy Program

College of Engineering

Seoul National University, Bldg \# 37

San 56-1, Shinlim-dong, Kwanak-gu

Seoul 151-742

South Korea

Email: heshmati@snu.ac.kr

\footnotetext{
${ }^{*}$ We are grateful to Professor Sunanda Sen and Dr. Byasdeb Dasgupta for their valuable comments. Amit K. Bhandari acknowledges the research project "Political Economy of Labour in the Globalized Economy", funded by "Indo-Dutch Programme for Alternatives in Development" for furnishing available data.
} 


\section{Introduction}

Flexibility in labour use has become one of the key sources of competitive advantage for firms in the age of globalisation. Flexible labour market implies the relaxation of 'rigid' rules and regulations governing employment and job condition of the labour. This requirement has become more pronounced in the post-globalised era as the economy has undergone fundamental transformation with the internationalisation of markets, technical innovations, advancement in information technology, increased flow of trade and capital. The globalization of country has made competition as one of the most important ingredient for development, expansion and industry's survival.

It is alleged that the stringent labour laws create obstacles in the successful implementation of structural adjustment programmes, preventing private sector or foreign investor from entering into business. Sachs et al (1999) attributed the low share of employment to the labour market rigidity. The degree of flexibility depends on many aspects of the labour market such as employment contracts, wages, working hours and work organisation (Sivananthiran, 2004). Job and employment security regulations create a network of restrictions that reduce the ability of the employer to adjust to the changing market conditions (Anant et al, 1999). To cope with such rigidities firms are attempted to find alternative route involving various forms of informalities in labour recruitment. Informalities take place in the form of contract worker, contract worker, temporary worker, agency worker, part-time worker and the like. This is leading to a two-tier workforce with less and less directly employed workers and increasing number of employed through contracts or agencies.

The key solution, in general, for almost all organization is to find out internal and external flexibility of employment. Internal flexibility is synonymous with work flexibility which involves time and the function of permanent workers, while job flexibility is an external process where the responsibility of job continuation is kept outside the organization. Hence, the external flexibility is applicable for casual or contract worker which is the central focus of this paper. The organisation would create a 'core' of high skilled employees who would participate in decision making and a 'periphery' of low skilled workers with little job security. Although the distinction between core and periphery workers is not clear as in many industries both permanent and contract workers are performing core functions (Smith, 2003).

The relationship between labour market flexibility and the process of casualisation of workforce is a well discussed issue ${ }^{1}$. There is a link between labour market deregulation and the process of informalization, casualisation, contractualisation and feminisation. ${ }^{2}$ The recruitment of casual or contract worker is usually regarded as an indicator of flexibility because conventional statutory regulation hardly applies to them. Besides, firms can also save high costs in the form of compensation that are given to the workers after the termination of contracts. As per Contract Labour Act state governments are empowered to abolish contract worker in any industry employing more than 100 workers. Owner of the company reacts to the changing demand by subcontracting its job or by recruiting worker without formal contracts or they can

\footnotetext{
${ }^{1}$ See Deshpande et al. (2004)

2 See Taylor (1993), Cornla (1989) and Standing (1989 and 1999). For discussion of labour market discrimination see Leblanc (1995), Carneiro et al. (2005) etc.
} 
move down to small units to keep the employment to the threshold level. ${ }^{3}$ This practice resulted in the segmentation of labour market. In one segment, there are permanent workers while the other segment comprised of contract and casual workers (Seth, 2004). Casual workers are considered as the most disadvantaged group of workers, a large majority of the casual labourers earn below poverty line income, and they also reflect the lowest labour standard in the country (Ghosh, 2003). Annual Survey of Industries (ASI) data suggests that employment through contractors constitute $23.08 \%$ of total organised workforce in 2003 compared to $11.03 \%$ in $1992 .^{4}$

Apart from the differences between contract and permanent workers in terms of job tenure and hire and fire norm, differences are there in the form of wages, benefits, job security and working conditions. Permanent workers are presumably protected and they can not be retrenched without prior permission and generally carries unionized status. On the other side, contract workers are unprotected and remain in that status despite working for many years in a firm. Now casualisation and contractualisation of labour is a global trend which resulted in the deprivation of fundamental benefits of their employment because of their job status. Apart from low wages, casual workers and their families are deprived of benefits like health, safety, welfare and social security.

The debate on insecurity has attracted considerable attention among the researchers in the age of globalization. There is no doubt that contemporary labour market has been increasingly dominated by job insecurity which is the direct outcome of the pressure from within the workforce for greater flexibility. More and more workers are found in the non-standard employment relationships, where employment and job insecurity is at stake. Employment security denotes the protection of employment against arbitrary dismissal or sudden loss of employment, while job security arises from the existence of institutions, regulations and practices that enable people to obtain and retain a position and to pursue an occupation (Standing, 1999). Indian labour market is a kind of anomalous labour market. In the organised labour market employment security is more important than security in income. Another type of labour market is where security of income is more important that security of employment. With the deregulation of market, increased global trade and investment, increased labour market insecurity seems to receive less attention among the policymakers. Among all forms of insecurities job insecurity is the most worrying aspect of insecurity. The feeling of job insecurity stems from low probability of getting another job.

Some researchers have attempted to compare the level of job insecurity over time or between countries by looking at the proportion of employees on non-permanent contracts, such as fixed terms, temporary, casual and agency contract. The survey has shown that employees on such contracts tend to report markedly lower levels of job insecurity (Robinson, 1999). The explanation for this is that those permanent workers are poorly protected from dismissal. Traditionally, permanent employments are strengthened by imposing regulation on hiring and firing practices. In our case, job insecurity denotes the fear of becoming unemployed and the difficulty of finding a new

\footnotetext{
${ }^{3}$ For detailed discussion see Lall and Mengistae (2005)

${ }^{4}$ In ASI no figure for casual workers can be found. Instead one gets data on employment through contractors.
} 
position after loosing a job ${ }^{5}$. Job security is a subjective feeling about the risk of job loss as expressed by employees themselves. Several existing surveys have used different formulations to measure security. Some ask employees to rate their present level of job security on a scale from 'very insecure' to 'very secure'. Some ask employees to access the risk of becoming unemployed in the next twelve months, while some other survey used multiple indicators to measure different aspects of job insecurity ${ }^{6}$.

To our knowledge so far not a single study is there discussing the wage difference between permanent and contract workers in organised manufacturing industries in India. This is mainly because of the non-availability of individual level observations on wage separately for permanent and contract workers. If the wage difference exists after controlling for personal characteristics, this difference would provide evidence of labour market discrimination outcomes by cost cutting. In addition we also examine the issue job insecurity among permanent and contract workers. We emphasize employee's self reporting as most important source of getting information of job insecurity. In this regard we seek to investigate the determinants that affect worker's perception on security of their present job. The empirical analysis is based on a primary survey carried out in selected industrial areas in India.

The paper proceeds as follows. Section 2 discusses the recent trend in the contractualisation of employment in Indian manufacturing industries. Section 3 discusses the theoretical issues involved in the study. Section 4 discusses about job insecurity and its determinants. This is followed by the basic model of the empirical analysis. The data set and variables are explained in the following section 6 . Section 7 provides the result of the survey. The final section sums up the major findings of the study.

\section{Contractualisation of Employment: Recent Trends}

In 1970, the Government of India enacted Contract Labour Act to regulate the employment of contract labour in certain establishments and to provide for its abolition under certain circumstances. The main aim was to prevent exploitation of contract workers. Under this act industrial establishments employing not less than 100 workers have to seek prior permission from the appropriate government department to effect layoff, retrenchment or closure. Deshpande (2004) did not find the evidence that firms that have employees more than hundred face greater hurdles in laying off workers when compared to the firms that employ less than hundred workers. Interestingly it has been observed that firms irrespective of size were found to increase employment mainly by increasing the share of non-permanent workers. The findings of Bhandari and Heshmati, (2005) reveals that to withstand in the competition and to cope with the rigidity in labour laws firms adopt their own tools to adjust labour to the optimal level ${ }^{7}$. Figure 1 presents the share of contract workers to the total workers in Indian manufacturing industries between 1992 and 2003. The share of contract worker

\footnotetext{
${ }^{5}$ For detailed discussion see Robinson (1999)

${ }^{6}$ See Burchell (2001)

${ }^{7}$ For details see Bhandari and Heshmati, (2005)
} 
increased after 1992 until 1994, fell in the year 1995-96, and remained fairly consistent until 2002-03. This indicates that manufacturing industries have already achieved substantial labour market flexibility through increase in the share of non-permanent workers in total employment.

Let us begin with a broad view of the structure of casual workers to the total employment for disaggregated industry level. The share of contract worker to the total workforce is used as a measure of the incidence of 'contractualisation' in the labour market. Table 1 presents the descriptive figures of employment structure of contract worker for different industries over different time periods. The period considered here is after the reform initiated in 1991. In addition to total period of the study (1992-2002), two sub periods are selected viz. 1992-98 and 1998-03 to investigate the change in contractualisation. At the disaggregate level the trend in contractualisation are observed for 21 two digit industries. Consider first the average percentage of contract worker to the total workers for the entire period, where tobacco industry is leading the group with the share of $53.4 \%$ contract workers to the total workforce. This followed by manufacturing of non metallic mineral (28.6\%), manufacturing of computing machinery (25.8\%), paper industry $(21.1 \%)$, petroleum $(30.03 \%)$, basic metal (24.80\%), food and beverage industry (18.4\%), fabricated metal $(17.7 \%)$, chemicals (17.1\%) and furniture (12.4\%) comprising top 10 industries using contract workers. Pharmaceutical industry ranks at the bottom in using contract worker, only $4 \%$ of the total worker are contract.

If we take a close look at those industries above we find that there is not uniformity in the structure of these industries where both capital intensive as well labour using industries are included in the group. Tobacco industry is purely labour intensive industry uses contract labour for the production of items like 'bidi' and chewing product like khaini etc are made in the household. Companies are contracted out the job to the local contractors rather than recruiting them in the factory. On the other hand pharmaceutical industry is in the front rank of India's science based industries generally. Since it is a highly organized and highly technology oriented the labour requirement in this sector is a highly trained and educated which is very difficult to manage production with contract worker.

\section{Theoretical Issues}

With respect to the distinction between permanent and contract workers, the latter appears to be more attractive for employers in terms of incentives and benefits that they are provided compared to the permanent or regular workers. It is generally presumed that wages received by casual worker are lower than wages received by permanent workers. This is understandable from the point of view of employer's strategy of cutting costs of production, although several other avenues are there for the possible cost reduction. Costs of a typical manufacturing firm can be divided into two parts labour and non-labour input costs. Firms hardly do anything to adjust its non-labour input cost directly in the short run as they face market determined prices as these factors are quasi fixed in the short run. Moreover, the non-labour cost is directly linked with the quality of the product. So firms can go for adjusting costs by cutting down its employment size. 
In the present circumstances, it is rarely observed that employer agreeing employees with long term contract which specify wages for the future. Otherwise employers are bound to pay higher wages to those workers which have got experienced after working for years. In light of these situations the demand for labour needs to be checked in terms of permanent and non permanent workers. Compared to the demand for non permanent workers the demand for permanent worker is inconclusive because of the presence of cost cutting approach by the firms. The human capital approach in this situation might provide insights into the debate of labour demand and supply interactions. Even if human capital gap are reduced the observed wage difference may remain intact keeping in view of the nature of labour demand. If the human capital gap is substantial in explaining the wage gap, then policies should be designed to enhance productivity enhancing characteristic of the workers. It is therefore important to investigate how much the role of human capital is there compared to the effect of cost cutting and the structure of labour demand.

The rise in labour use flexibility leads to the rise in the use of non-permanent workers. The growing informalisation of workforce through casualisation and contract recruitment resulted in the rise in job insecurity. Informalisation is a process which occurred at the entire socio-economic space and also at formal factory space. The increased job insecurity is associated with part time employment causing thereby frequent mobility from one job to another (Fleetwood, 2003). From employer's perspective casualisation of labour is beneficial for industry's competitiveness but it is a matter of concern for the workers as the incidence of job insecurity is highest among contract workers, because they are not covered by employment protection. A permanent worker works under job protection legislation while a temporary or contract worker works under continual worry that his/her contract might not be extended.

\section{Factors Influencing Job Insecurity}

Recent years of workplace is characterized by downsizing, two tiered occupation structures, outsourcing ${ }^{8}$ and contingent labour which may indicate that job insecurity is likely the dominant features of the new era of specialization (Walance and Brady, 2001). Millions of workers have lost their job for no fault of their own; millions of workers have been directly or indirectly affected by these dislocations. Tens of millions of workers who survived these wrenching changes have had to cope with increased job insecurity, heightened levels of stress and increased feeling of anxiety, cynicism and alienation ${ }^{9}$. The incidence of perceived job insecurity entails several attributes. Job insecurity included not only the fear of loosing job but also the fear of loosing valued feature of job such as: promotional opportunity, control over the place of work, the ability to complete entire job, customary pay hikes and access to representation (Burchell, 1999).

The increased job insecurity has different organizational implications (Hartley, 1997). Employees who feel insecure are more likely to be resistant to and oppose any changes being introduced and because they are feeling stressed this will impact on the

\footnotetext{
${ }^{8}$ For a survey on outsourcing in manufacturing and service industries see Heshmati (2003).

${ }^{9}$ See Burke and Cooper (2000)
} 
organizational effectiveness and efficiency (Greenhaugh and Sulton, 1991). In studying the effect of job insecurity in a large Australian public transport organization undergoing significant changes and downsizing Dekker and Schaufeli (1995) have found that job insecurity is associated with a deterioration of psychological health as well as job or organizational withdrawal. However, social support from colleagues, from management or from unions had no effect. They also found significant relationship between job insecurity and work related outcomes. The higher the levels of perceived insecurity lower the job commitment and more negative appraisal of one's career. Job security is also linked to moral and motivated commitment of the organization. Insecurity arises from uncertainty within the organization which is applicable during downsizing. The feelings of job insecurity are associated with stress (Hartley, 1996). As far as external labour market factors are concerned job insecurity arising from the perceived vulnerability to unemployment (Litter, 2000).

A rise in job insecurity is also related with the secured earning ability for a sustainable living. Increasing income security may not go hand in hand with job security (Sen and Dasgupta, 2006). In addition to the rise in unstable wages there would be the insecurity of inadequate health care, inadequate medical benefits, disability benefits and retirement benefits ${ }^{10}$. A rise in the feeling of insecurity may also stem from the rise in labour market experience. Whether increased job experience would reduce worker's job insecurity is doubtful. Newly joined workers may feel more insecure than their counterparts who are senior to them in the job market because of their low exposure in the labour market. Another possibility is that workers with long term contract may feel insecure because of any unfavorable circumstances. It is generally held that long duration in a job increases job security.

Rising level of education are perceived as an important component in human capital formation. Workers with more schooling may face lower job insecurity if the education is more employment oriented. Similarly, skill and special training of work also play crucial role in quality improvement. Improvement in qualifications is presumed to affect job security positively. Other labour market attributes such as union membership, relationship with supervisor and migration are expected to reduce job insecurity.

\section{The Model and Estimation}

In this section, we analyse how various characteristics of manufacturing employment account for the wage gap between permanent and contract workers. In this regard, we explore issues such as worker's qualification and labour market characteristics on earning by using a standard econometric analysis of wage structure. The earning equation has been estimated following standard Mincerian earning function derived from human capital model which enable us to investigate whether contract workers are discriminated when all else are equal. In the basic model we estimate earning equation assuming Mincerian ${ }^{11}$ earning function as:

$W_{i}=\beta X_{i}+\varepsilon_{i}$

\footnotetext{
${ }^{10}$ See Rubin (1995)

${ }^{11}$ See Mincer (1974)
} 
where $W_{i}$ is the natural logarithm of hourly wage or earning, $X_{i}$ denotes a set of variables controlling human capital and job related characteristics (see Appendix for the list of variables), $\beta$ denotes unknown effects of the variables on hourly wage to be estimated and $\varepsilon_{i}$ is a random error term which are assumed to satisfy usual properties. As par human capital theory, education and experience bear positive influence on an individual earning and the earning function is concave in experience, implies that experience affect positively on earning but at decreasing rate. The earning function can further be extended by incorporating job related characteristics of the workers like migration, skill, special training, union membership and the like.

Wage equations are estimated separately for both permanent and contract workers to investigate differential in the return of variables considered in the study. Using same specification, we compare the wages of permanent and contract workers by running regression of the following form:

$W_{i}^{j}=\beta X_{i}^{j}+\varepsilon_{i}^{j}$

where the subscript $\mathrm{j}$ denotes worker's type, $\mathrm{j}=$ (Permanent, Contract). The variables included in these equations are the same as in the earlier equation with the exception of worker's type dummy.

Following Oaxaca (1973) we explore this issue by using a standard earning decomposition $^{12}$. In the typical decomposition model one part of the wage gap is due to the differences in observable personal characteristics between the two groups while the remaining part remains unexplained. We estimate separate permanent and contract wage equation as:

$\bar{W}_{P}=\hat{\beta}_{P} \bar{X}_{P}$

$\bar{W}_{C}=\hat{\beta}_{C} \bar{X}_{C}$

where the hats denotes estimated parameters and bars over variables indicate sample mean. $\bar{W}_{P}$ and $\bar{W}_{C}$ refers to the estimated mean wage received by each permanent and contract worker respectively.

The overall gap ${ }^{13}$ between permanent and casual workers is expressed as:

$$
\begin{aligned}
\Delta W=\bar{W}_{P}-\bar{W}_{C} & =\left(\bar{X}_{P}-\bar{X}_{C}\right) \hat{\beta}_{P}+\bar{X}_{C}\left(\hat{\beta}_{P}-\hat{\beta}_{C}\right) \\
& =\left(\bar{X}_{P}-\bar{X}_{C}\right) \hat{\beta}_{C}+\bar{X}_{P}\left(\hat{\beta}_{P}-\hat{\beta}_{C}\right)
\end{aligned}
$$

The average wage differential between permanent and casual workers is decomposed into two components in (5) and (6). The first term on the right hand side is the part of the wage gap attributable to the differences in qualification between permanent and casual workers using permanent coefficients. This component is generally referred to as

\footnotetext{
${ }^{12}$ See also Blinder (1973)

${ }^{13}$ First $\hat{\beta}_{P} \bar{X}_{C}$ is added to both of the equations (3) and (4) and then equation (3) is subtracted from (4). Secondly, $\hat{\beta}_{C} \bar{X}_{P}$ is added and follows the same procedure.
} 
explained wage gap. This situation corresponds to the wage gap where there is no discrimination, that is, permanent worker's characteristics are rewarded like that of casual workers. The second term represents the conventional measure of wage discrimination attributable to the difference in higher prices $\left.\left(\beta_{P}\right\rangle \beta_{C}\right)$ received by permanent workers for those characteristics. Since this part is not controlled for and are referred to as unexplained gap.

Equation (6) is an alternative representation of the wage gap, using casual coefficients to evaluate the difference in mean characteristics. It is assumed that in the absence of discrimination there exist casual wage structures as a true wage structure. These two equations represent two extreme cases. It is most likely that the real values would fall in between them. This method is attached with index number problem. The decomposition of differences in earning is the estimates of what a permanent worker receives if he faced the casual wage structure or vice versa. An appropriate reference group can avoid this problem. The selection of which is a matter of debate, which can not be precisely estimated, any value falling between permanent and casual coefficient can be considered as equilibrium value. According to Neumark (1988) non discriminatory wage structure can be computed by estimating earning function over the pooled sample. However, Silber (2000) tests five techniques ${ }^{14}$ and found that there is no significant difference in the results between them.

To access insecurity among the workers the qualitative information of insecurity is collected from worker's perception about job securities. The level of perception can be viewed as a continuous variable by which one can get the information regarding the degree from the feeling of insecurity. Hence job insecurity of an individual worker can be viewed as dichotomous measure. In the present context, a worker is considered to have insecure only when he expressed his feeling on insecurity in his current job. Hence, a worker's perception of the security of the present jobs takes the form of a binary variable and can be analyzed by logistic regression models. To investigate the magnitude of impact of the factors on job insecurity we use a binary logistic regression. The explanatory variables contain both qualitative as well as quantitative variables ${ }^{15}$. In the following binomial logistic regression model, we have estimated the probability that worker expressed his/her fear on job security. If P is the probability of job insecurity, then:

$$
P_{i}=P_{i}\left(Y_{i}=1\right)=E\left(J_{i} / X_{i}\right)=1 /\left(1+e^{-\left(\beta_{i}+\beta_{2} X_{i}\right)}\right)
$$

where $X_{j}$ contain variables in question and $\beta_{j}$ is the corresponding regression coefficients. Job security, a binary dependent variable, is assigned the value of one if the worker expressed their job as insecure and zero otherwise. In our case, this is the simultaneous effect of personal and labour market related attributes of worker's perception on job security.

Equation (7) gives the positive response of job insecurity. Under this specification the negative response on job insecurity is expresses as:

\footnotetext{
${ }^{14}$ Raimers (1983), Cotton (1988), Newmark (1988), Oaxaca (1973) and Oaxaca and Ransom (1994)

${ }^{15}$ See Hamilton (1992)
} 


$$
1-P_{i}=1-1 /\left(1+e^{-\left(\beta_{1}+\beta_{2} X_{i}\right)}\right)=e^{-\left(\beta_{1}+\beta_{2} X_{i}\right)} /\left(1+e^{-\left(\beta_{1}+\beta_{2} X_{i}\right)}\right)
$$

Dividing the $\mathrm{P}_{\mathrm{i}}$ by 1- $\mathrm{P}_{\mathrm{i}}$ gives the odd ratio in favor of a worker expressing his concern of job security:

$P_{i} / 1-P_{i}=e^{\beta_{1}+\beta_{2} X_{i}}$

Taking natural log of both sides it is written as:

$$
\log _{e}\left[P_{i} /\left(1-P_{i}\right)\right]=\beta_{j} X_{j}
$$

After appending an error term $(\varepsilon)$ we will estimate the equation (10) by using maximum likelihood estimation method ${ }^{16}$.

\section{Data, Sample and Definition of Variables}

The data used in this study are from a primary study conducted by Indo-Dutch Programme for Alternatives in Development (IDPAD) - a sponsored research project on "Political economy of labour in a globalised economy". The uniqueness of the survey is that it contains information on wage distribution of permanent and contract workers separately and on their characteristics. This data was collected from some selected industrial areas in West Bengal, including Uttar Predesh, Haryana and Delhi during 2004-05.

The survey includes a total of 551 workers of different factories in the organized manufacturing sector. The information is collected from the factory workers in these regions on the basis of a structured questionnaire. The samples were randomly collected within the framework that the number of workers was restricted to at most five in a firm so as to cover diverse industries. Dividing the region into two regions the number of workers surveyed in the eastern part of the country is 312, while in the northern part the number is 239. For the sake of comparability major attention was given in selecting the type of workers in a firm so that the sample become well representative of both permanent and contract workers. Of the total number of workers in our sample, 271 are permanent workers and 280 are contract workers.

Industries surveyed were classified according to the National Industrial Classification (NIC) 1998. In West Bengal the survey was conducted in Kolkata, Howrah, Hooghly, Kalyani and Falta. Of them Kolkata, Howrah and Hooghly are old industrial areas, Kalyani was built up as an industrial town after Independence and Falta appeared in industrial map of West Bengal in the mid 1980s as an export processing zone (now it is called Special Economic Zone). In West Bengal, among the total workers interviewed $32.1 \%$ workers were from Kolkata, from Howrah 9.3\%, from Hooghly 6.1\%, from Kalyani 38.8\% and from Falta 13.8\%. The survey area of Delhi includes East Delhi, Okhla and Mayapuri, Uttar Pradesh includes Noida, Ghaziabad \& Sahibabad, Haryana includes Gurgaon and Faridabad. The only Special Economic Zone in this area is situated in Noida.

${ }^{16}$ See Seddighi(2000) 
The survey questionnaire was designed to contain information pertaining to wages and benefits, work condition, job condition, job security, firm specific information, socio economic characteristics etc. Table 3 presents the summary statistics of the categorical distribution of workers in our sample. In the total sample the proportions of permanent and contract worker are $49.2 \%$ and $50.8 \%$ respectively. As regard to workers concern about job security of the total sample $52.26 \%$ of the workers expressed their concern over their job security.

\subsection{Analysis of Worker's Remuneration}

In the sample studied here we have considered that permanent and casual workers as a homogeneous group in our sample. The average wage of a worker is Rs. 15.6, while the average wage of a permanent and contract worker is Rs. 19.9 and Rs. 11.3 respectively For permanent workers the gross hourly wage is obtained by dividing monthly gross income by number of days work in a month and again by the number of hours worked in a day. For temporary or contract worker wages are found to be paid on daily or weekly or even monthly basis, which are converted into hourly wages accordingly. The distribution of wages according to the characteristics of human capital as well as by a number of labour markets attributes as follows.

\section{(i) Education}

It is generally held that education has positive effect on earnings and bargaining power $^{17}$. According to conventional wisdom differences in level of schooling is the key driver of inequality ${ }^{18}$. It is widely accepted that education increases earning capacity through its effect upon individual productivity (Colclough, 1998). If wage differs in parts by the difference in the level of education the choice of different levels of education should explain the part of the wage gap. In our study education variable is recorded as five categories: literate and primary (1-4 years), basic (from 5-8 years), secondary (10 years), higher secondary (11-12 years) and graduation and above (12+ years). The lower category of education is used as a reference level of education. Education variable is used in our analysis as education level dummy variables. As can be seen from Table 2 most of the workers do have basic and secondary level education. With few exceptions, educational distribution among permanent and contract workers are almost the same. As can be seen form Table 3, average wage increases with the level of education. Interestingly for contact worker with a graduate degree earn less than worker with secondary level of schooling. The difference between wages of permanent and contract worker is considerable, about $57.5 \%$ when both groups are graduates, while lowest wage difference is found among workers with basic education, where the wage difference is $38 \%$.

\section{(ii) Experience and Seniority}

Conventional measure of actual work experience of an individual worker is the difference between the potential work experience and the number of years out of labour force. However, in most of the cases we ran into trouble as the workers failed to recall

\footnotetext{
${ }^{17}$ See Becker (1964)

${ }^{18}$ For details of the impact of education on earning is provided in World Bank (2000)
} 
the definite figure of how many years they are working and for how many years (if at all) they remained out of labour force. Hence, as a proxy of work experience we include the number of years involved in the present job. We hold here that the more is the experiences in terms of years worked in a job the more scope will be there for moving to the upper pay scale and designation in the same factory. It is important to mention that the job tenure of casual workers is important particularly because of their changing nature of job from one firm to another. Hence, it is expected that permanent workers, due to their relatively higher experience in job, get the scope of higher income than their counterpart. On average, permanent worker have 12.6 years of work experience, compared to 3.8 years for contract workers. Categorizing worker's experience into four categories (less than 2 years, 3-5 years, 6-10 years and more than 10 years) reveals considerable difference in level of experience, where $45.8 \%$ permanent workers have 10 or more years of experience. Average wages increases with the years of experience.

(iii) Skill

The skill of an individual worker is assumed to play important role for higher earning opportunity. Skill is a heterogeneous concept ${ }^{19}$, by skill we mean particular quantities of work necessary for working in a factory ${ }^{20}$. Unskilled workers are those workers whose work does not require any special knowledge and /or quality. Improvement in skills produces better labour market outcomes. Hence, differences in skill among the workers should account for the wage gap between permanent and contract workers. In our sample we have categorized workers as skilled and unskilled in terms of possession of general skill necessary for the particular job. We find that about $84 \%$ of the workers are skilled. However, in most of the cases they acquired skill through learning by doing or from prior experience of working at other firms. Proportion of skilled permanent worker is higher than their contract worker counterpart. On average there is no major difference in the level of earning between permanent and contact workers in distinguished by skill.

\section{(iv) Advanced Skill}

As mentioned earlier, access to training enhances the scope for acquiring skill and thereby, increases the probability of an individual's level of productivity as well as earning opportunities. Therefore, wage difference among workers might explain by the differences in access to special training, provided that workers training are suitably applied by their employer. Advanced training is generally not provided in school or collages; they get this either from some training institute for technical skill before entering the current job or by employers after entering the job. In our sample we find that the proportion of worker with advanced skill is $16.3 \%$. Classified by worker's category, the proportion of worker with advanced skill is greater for permanent worker (20.3\%) than their counterpart (12.5\%). Classified on the basis of advanced skill,

\footnotetext{
${ }^{19}$ See Bills (2004)

${ }^{20}$ In the recent time skilled and unskilled distinction is made on the basis of general educational level of a worker. Generally education may help to broaden the knowledge basic of an individual but it may be sufficient for his/her to perform a particular kind of work. The latter may require certain apprenticeship which is additional to the general level of education. This apprenticeship is additional to the general level of education. This apprenticeship may be inculcated through professional courses, technical education and/or lower training.
} 
permanent worker receive higher wages than contract worker. As far as hourly wage received by permanent worker is concerned, they receive Rs. 27.7 whereas casual worker receive only Rs. 13.8 .

\section{(v) Union Membership}

It is accepted that union membership is a critical factor to reap the fruit of wage bargaining with the employer. This is a two way relationships. Cross sectional studies have been able to investigate the impact of various measures of wages and earnings on union membership find a positive relationship ${ }^{21}$. The probability of unionization first increases with earnings and after a certain wage level it decreases. This decrease may reflect increased employer opposition to the unionization of highly paid employees that usually occupy higher hierarchal positions in a firm. In the sample studied here union membership is pronounced among the permanent workers because they tend to stick to a job for a longer period owing to their permanent tenureship. The difference might be due to cost of membership or alternatively reflecting discrimination against union members at the time of employment. The relative wag advantage of union membership is significantly higher for permanent worker than contract worker (see Table 3). There is no significant wage difference among contract unionized and non-unionized workers (Rs. 11.6 and Rs. 11.2, respectively).

\section{(vi) Migration}

Migration can be treated as an explanatory variable affecting worker's earning. Migration here reflects migration between regions rather than between jobs. Inter regional migration is assumed to bring benefits to the workers of underdeveloped regions. Migration brings income disparities and inequality within urban areas and the effect is much more pronounced when their families migrate ${ }^{22}$. The rate of migration is assumed to be driven by income insecurity. By income security we mean that migrant worker might not earn a minimum level of income on a sustained basis necessary for his/her subsistence. But when a worker migrates the employer may take advantage of his/her vulnerability and may offer a job with lower remuneration than the existing workers in the firm, particularly for the permanent workers. In our case the average hourly wage of non migrant permanent workers is Rs. 20.8, this is higher than average hourly wage of non-migrant permanent worker which is Rs. 17.3. Not much wage difference is found among migrant and non-migrant contract workers. On the whole, migrant workers are less paid than non-migrant.

\section{(vii) Industry Characteristics}

Industry structure is presumed to play crucial role on the worker's earning. In addition to other factors the concentration of a particular industry depends on the availability of skilled workers. It is expected that workers will be benefited from working in those industries which have a high regional concentration. Industries included in the survey are classified following two digits National Industrial Classification from 1998 - food, textile, wearing apparel, chemical, rubber/plastic, electrical machinery and transport industry. In our sample food, chemical, plastic, electrical and transport constitute majority of the workers. The highest hourly wage level is found in motor vehicle

\footnotetext{
${ }^{21}$ For details see International Handbooks of Trade Unions (2003)

${ }^{22}$ Atinc (1998)
} 
industry (Rs. 21.5), whereas leather industry followed next with the average wage of Rs. 20. As far as permanent workers are concerned the highest hourly wage received from machinery industry (Rs. 28.5), followed by electrical machinery (Rs.23.5), motor vehicle (Rs. 23.3) and leather industry (Rs. 22.4). On the other hand, the highest hourly wage received by a casual worker is from leather industry (Rs. 16.3) and printing publishing industry (Rs. 16.3). Dummy variables for industries listed above for each region are used in the estimation, while 'other industries' are excluded as a reference industry category.

\section{Empirical Results}

\subsection{Determinants of Hourly Wage}

In this study two alternative specification of measurement have been used to estimate the contribution of worker's characteristics and the discrimination to the overall gap between permanent and contract workers. Table 5 reports the result of the estimated earning equation for the total sample workers while Table 6 reports the results of the estimated earning equation for permanent and contact worker separately. Overall, the model fits the data relatively well and most of the coefficients have expected signs and significance levels. The coefficient of casual dummy shows that permanent workers are expected to earn $45.5 \%$ more income than their contract worker counterpart ${ }^{23}$. A positive association is obtained consistently between successive higher levels of education. As expected, the coefficient of experience variable is positive and statistically significant. There is a conventional concave relation between earnings and experience. There is no significant return to the workers with general skill. In fact, advanced skill has significant effect on earnings. Migrant workers belong to the disadvantaged group whose earning is significantly lower than non-migrant workers. Union membership enhances worker's bargaining position. Lastly, workers working in special economic zone are paid significantly lower wage compared to other places of the study, implying that enterprises are taking advantage of low wages in this zone.

In the next step we have presented the result of the decomposition results using the Oaxaca decomposition technique and compared the effects of the difference in relative endowments of human capital between permanent and contract workers and the labour market discrimination on the level of monthly wages (see Table 6). We have used the coefficients of the estimated earning equation of permanent and contract workers to decompose wage difference between them which are discussed in the next section.

\subsection{Decomposition of the Wage Gap}

The mean log hourly wage difference is 0.625 . Table 7 reports the result of reducedform decomposition of the estimated wage gap between permanent and contract workers. The difference in endowments of personal characteristics explains (0.215) or $34.3 \%$ of the gap in the log hourly earnings when evaluated with permanent worker's coefficients. This leaves an unexplained earning difference of $(0.410)$ or $65.7 \%$ of the gap in earnings. When evaluated with contract workers coefficients, the explained and

${ }^{23}$ Conversion of the log difference to percentage difference is conducted by using the formula [exp(.)-1] 
unexplained parts of the pay gap are $30.2 \%$ and $69.8 \%$ respectively. Thus, the earning gap for the difference in unobserved characteristics is the dominant component, which indicates that casual worker's characteristics are valued less than that of permanent workers. The reported estimated coefficients of permanent and contract workers are from obtained from estimation of equation (3) and (4) (See Table 6).

What are the relative importances of personal characteristics of workers in explaining permanent-contract wage gap? The coefficients on the experience variable are positive and statistically significant for both permanent and contract workers. Measured with permanent coefficients, the experience variable explains $24 \%$ of the difference in earnings. If evaluating with contract worker's coefficients, the experience component accounts for $25.5 \%$ of the pay difference. As workers work for longer period in a factory, it is likely that their wage return would increase. However, it needs to be mentioned that the scope for upward mobility of contract workers is very limited. There is no significant effect of general skill on the earning for both types of workers. Coefficients of advanced skill are jointly significant for both permanent and contact workers. However, the wage premium received by permanent worker is much greater than their counterpart. This is a reflection of the labour hoardings in the Indian labour market. Employers are giving higher wages to the permanent workers for their core activities. Differences in advanced skill explain 3.9\% of the pay difference when evaluated with permanent coefficients while $0.5 \%$ when evaluated with contract worker's coefficients. At the same time employers are able to access necessary skills to adjust their labour force to a desired level and skill composition by taking advantage of the flexibility of the labour market. Increasing education attainment by casual workers does not contribute much in reducing their wage gap. If other factors are constant, the observed differences in education account for $0.8-2.14 \%$ of the wage gap.

Furthermore, union status pays significantly more wages to casual workers than permanent workers. The proportional of the wage gap attributable to the difference in union membership is $0.2-1.8 \%$. Labour unions are generally bestowed with permanent workers, while the union presence among casual workers is marginal. Changing union membership does not explain on the wage gap. Industry characteristics explain 3.5 to $6.5 \%$ of the wage difference among the two worker categories. Other characteristics play very minor role in explaining the pay difference among the sample workers.

\subsection{Logit Regression Analysis}

The logit regression results are reported in Table 9. Three sets of logit regression are estimated by using as dependent variable the workers' feeling of insecurity in their present job. The first column reports estimates based on aggregate sample workers. The remaining columns present the estimates of permanent and casual workers respectively. This will allow for study of heterogeneity in workers feeling of insecurity by type of employment.

In the case of total workers the coefficient of determinants indicates reasonably statistically significant fit. Contrary to the expectations, the estimates reported in column 1 of Table 9 indicate that permanent employment status has positively influences on workers perception on job insecurity. More specifically, permanent workers are more concerned about their present job than the casual workers. Among the 
variables of personal characteristics, level of education has negative impact on the feeling of job insecurity. Workers with higher education are more likely to find another job if their present job is lost. Education is measured as number of years spent in school and colleges. For permanent workers, level of education has positive influence on job insecurity, although the effect is negative for casual workers. Since casual workers are to change their jobs frequently extra education likely increases the feeling of job security. The probability of the workers' feeling of job insecurity decreases with the increase in earning. If a worker feels that the loss of job is followed by extra earnings generated from the savings of his/her income from the previous job then the feeling of job insecurity may fall.

For temporary workers, higher income negatively influences job insecurity while the effect is not significant for permanent workers. Job duration and insecurity are positively related for the total sample as well as for permanent and casual workers, although only significant effect is found for temporary workers. For temporary workers, shorter duration of job is associated with increased mobility from one job to another, with the increase in experience in a particular job increases the likelihood of getting dismissed. General skill significantly influences the worker's feeling of job insecurity. The coefficient is large for casual workers. Special training also significantly increases the likelihood of job insecurity. If one fears that his/her skill is obsolescent, his/her perceived value would decline, hence intensifying the feeling of job insecurity (Standing, 2002).

Apart from the personal characteristics of the workers, other labour market attributes have negative relationship with job insecurity. To consider union membership first, taking all workers into account, workers with union member have 1.6 times less likely to feel insecurity of their present job. As expected, the likelihood of a worker's feeling of insecurity decreases more for permanent workers (3.72 times) than for casual workers (1.01 times). It should also be mentioned that as far as the role of union on temporary workers is concerned, unions have found it more difficult to organize 'flexiworkers' (e.g., temporary and casual workers, contract and freelance worker etc) because of organizational difficulty of retaining such workers, the tendency of them not to identify with union, the difficulty of integrations of flexi-workers into union structure and the legal ambiguity over the position of contingent workers ${ }^{24}$.

\section{Summary and Conclusions}

Summing up our discussion it can be said that casual workers are discriminated against the permanent workers. We find a substantial wage gap exists between permanent and contract workers where contract worker earn $45.5 \%$ less than their counterpart. We have used a standard regression based decomposition to investigate the earning difference between permanent and contract workers. Two alternative specification of the wage equation including hourly and monthly wages have been used to estimate the contribution of worker's characteristics and the discrimination to the overall gap between permanent and contract workers.

${ }^{24}$ For details see Standing (1999) 
The decomposition result shows that controlling for various observed characteristics experience plays the most important role in explaining the pay difference. In this regard, it should be noted that average contract worker can not stick to a particular job for a long period, could not reap the benefit of significant wage return like that of an average permanent worker. Hence, contract workers can not be able to improve their quality in terms of job experience. Even if a contract worker gathers experience by working in several firms one after another, their combined job experience often fails to provide premium to their wages. Other factors like education, skill, training, migration play insignificant role in explaining earning level does not hold in its entirety. Industry characteristics play third highest factors in explaining wage difference between permanent and casual workers.

A large part of the wage gap is not explained. What would be the interpretation of the unexplained gap? There are at least two possible avenues of the wage gap: firstly, the productivity differences among permanent and casual and secondly the discrimination against casual workers, as neo-classical theory relate workers wage according to their productivity. Empirically it is not possible to determine level of worker's productivity by different characteristics of the workers such as their gender; permanent-contract etc. Worker's productivity is correlated with their capabilities which are captured through work experience, education, skill etc (Smith, 2002). The present study does not find the above characteristics as dominant factors which are responsible for the size of the wage gap. In addition, we have taken homogeneous groups of workers working with the same type of work within their stipulated working hours. Thus, there is an ample possibility of discrimination which is attributable to the cost cutting strategy of firms. Clearly the use of contract workers is perceived as a cost cutting device which is one of the common phenomenons in the present globalised world. Is spite of being used as a cost cutting mechanism the important fact is that the increasing use of casual workers might discourage work effort of the workers for not being able to acquire enterprise specific skills which mitigate the advantage to the firms to take benefits from their prior work experience.

In response to the changing economic environment, supplemented by changing aspects of technology the new management practice requires flexibility in labour use so that the number of workers would not be fixed always. In this context companies opt for casual/contract workers to support the changing product demand. Why firms adjust wage cost by paying low wages to them? By using casualization/contractualization firms achieve both employment flexibility and cost adjustment goals. Shorter job tenure of casual workers restricted their vertical mobility. There should be paid equal wage as par permanent workers with equal quality; rather higher wages should be for the casual workers because of their unforeseen job tenure, for the absence of vertical mobility and as a compensation for discontinuity in earnings flows. Any regulatory intervention in improving labour standard of the casual worker may dampen the competitiveness of the industry. Flexibility in the use of permanent worker may ensure earning equality. Trade union must leave their discriminatory path and provide bargaining power to them.

The growth in labour use flexibility has been associated with increasing employment insecurity which is also assumed to be driven by casualisation and contractualisation. Is the feel of job insecurity higher for permanent workers? Contrary to the theoretical explanation, our study reveals that permanent employment status has significant effect the likelihood of workers feeling of job insecurity. Casual and temporary workers 
report less job insecurity than their full time or permanent counterpart. We use a binomial logit model to estimate the impact of personal qualification and some external factors on job insecurity. Education and income affect negatively the feeling of job insecurity for aggregate sample, while the effects are positive for permanent workers. Higher employment duration significantly increases the likelihood of getting dismissed from the present job. Workers having general skill and special training also increases the likelihood of the feeling on job insecurity. Hence more educated and skilled worker expressed their concern about their job security. As far as the labour market features are concerned union membership, relation with supervisor and migration provide relief as far as job insecurity is concerned.

As a policy prescription it is probably not entirely correct to say that by increasing workers qualification one would be able to reduce wage difference. This can only be applicable if there is a supply side constraint of labour. This proposition is not tenable in the labour surplus like country like India. The nature of labour demand should be studied carefully before arriving at final conclusions. Based on the available evidences the labour demand is toward contractualisation considering the cost cutting strategy of the Indian firms. In this study, the large discrimination component of the wage gap also corroborates this argument. As far as the job security is concerned appropriate policy should be introduced to prevent segmentation of the labour market in the form of permanent and contract employment.

The whole discussion becomes the part of the recent spurt in the recruitment of casual/contract workers and its underlying motivation. The study also highlights some related issues required to be investigated for further research. The future research should focus more on the proxy measures of productivity and its impact on pay difference between workers. What happens with non-production workers? How firms behave towards those workers? Finally, one might enquire whether the same phenomenon occurs for service sector workers. To emphasize the impact of liberalization on the wage gap the future research should focus on manufacturing involving in the export market. But most importantly, in the end it needs to be mentioned that labour flexibility has caused the casual labourers to bear the main cost of openness and globalization of the Indian economy. The cost in terms of lower wages and benefits is imposed on them for the firms to cope with uncertainty in a globalised economy. The field survey data is comprised of only private manufacturing companies. Workers working in the public manufacturing units might report different result. Nevertheless, this paper does provide valuable insight on the wage difference and the issue of job insecurity and predicting the factors affecting a worker's feeling of job insecurity. 


\section{References}

Anant T., K. Sundaram and S. Tendulkar (1999): Employment and labour in South Asia, New Delhi, ILO South Asia Multidisciplinary Advisory Team

Atinc, T. M. (1998): Sharing Rising Income Disparities in China, World Bank Publications

Auer, P. (2005): Protected mobility for employment and decent work: Labour market security in a globalised world, Employment Strategy Papers, International Labour Office (ILO)

Becker, Gary. 1964. Human capital: a theoretical and empirical analysis with special reference to education. New York: National Bureau of Economic Research.

Bhandari, A. and A. Heshmati (2005): Labour Use and its Adjustment in Indian Manufacturing Industries, Global Economic Review, Vol. 34, No. 3, 261-290

Bills (2004): Sociology of Education and Work, Blackwell Publishing

Blinder, A. (1973): Wage Discrimination: Reduced Form and Structural Estimates, Journal of Human Resources, Vol. 8, pp. 436-455

Borjas G.J. (1999): The economic analysis of immigration, Handbook of Labor Economics, Volume 3, Part 1, Chapter 28, 1697-1760.

Burchell, B. D. Dey, M. Hudson, D. Lapido, R. Mankelow, J. Nolan, H. Reed, I. Wichert and F. Wilkinson (1999): Job Insecurity and Work Intensification, York: Joseph Rowntree Foundation

Burke, R. J. and C. L. Cooper (2000): The Organization in Crisis, Blackwell Publishing

Carneiro, P. J.J. Heckman and D.V. Masterov (2005): Labor Market Discrimination and Racial Differences in Premarket Factors, IZA Discussion Papers 2005:1453.

Colclough, C. (1998): Marketizing Education and Health in Developing Countries, Oxford University Press

Cornia, G. A. et al (1989): Adjustment with a human Face, Vol. I and II: Protecting the Vulnerable and Promoting Growth, Clarendon Press

Cotton (1988): On Decomposition of Wage Differentials, The Review of Economics and Statistics, Vol. 70, No. 2, 236-343

Dekker, S. W. A. and Schaufeli, W. B. (1995): The effects of job insecurity on psychological health and withdrawal: A longitudinal study, Australian Psychologist, 30, 57-63

Deshpande, L. K et al (2004): Liberalisation and Labour: Labour Flexibility in Manufacturing, Institute for Human Development, New Delhi.

Deshpande, L. K., A. N. Sharma, A. K. Karan and S. Sarkar (2004): Liberalisation and Labour; Labour Flexibility to Indian Manufacturing, Institute of Human Development, New Delhi 
Fleetwood, S. (2003): Conceptualizing unemployment in a period of atypical employment: a critical realistic approach, in P. Downward edited Applied Economics and the Critical Realist Critique, Routledge (UK)

Ghosh, A. K. (2003): Jobs and Incomes in a Globalizing World, International Labour Office, Geneva

Greenhaugh, L. and Sutton, R. I. (1991): In J. F. Hartley, D. Jacobson, B. Klandermans and T. van Vouren (eds) Job insecurity: coping with job with risks, London Sage

Hamilton, L. C. (1992): Regression with Graphics: A Second Course in Applied Statistics, California

Hanushek, E. (1986): The economics of schooling: Production and efficiency in public schools, Journal of Economic Literature, XXIV, 1141-1177.

Hartley, J. (1996): Models of job insecurity and coping strategies by organizations, in M. Marmot, J. Merrie and F. Zingilo (eds.) Labour market changes and job insecurity: A challenge for social welfare and health promotion, Copenhagen, World Health Organization

Hartley, J. (1997): Organizational Change, In P. Warr (ed.) Psychology at work, Harmondsworth, Penguin

Heckman, J.J. and P.E. Todd (2003): Fifty Years of Mincer Earnings Regressions, IZA Discussion Paper 2003:775.

Heckman, J.J., L. Locher and P.E. Todd (2005): Earning Equations, Rates of Return and Treatment Effects: The Mincer Equation and Beyond, IZA Discussion Paper 2005:1700.

Heshmati, A. (2003): Productivity Growth, Efficiency and Outsourcing in Manufacturing and Services, Journal of Economic Surveys, 17(1), 79-112.

International handbook of trade unions (2003): Edward Elgar Publishing

Juhn, C., K. Murphy and B. Pierce (1991): Accounting for the slowdown in black-white wage convergence, In: Kosters, M. H. (Ed.), workers and Their Wages. AEL Press, Washington, DC, pp. 107-143

Lall, S. V. and T. Mengistae (2005): The impact of business environment and economic geography on plant level: productivity: an analysis of Indian industry, World Bank Policy Research Working Paper No. 3664, July 2005

Lenlanc, G. (1995): Discrimination in the Labour Market, The Canadian Journal of Economics, Vol. 28, No. 8 (Aug 1995), 702-717

Litter, C. R. (2000): Comparing the downsizing experiences of three countries: a restructuring cycle, in R. J. Burke and C. L Cooper (eds.) The Organization in Crisis, Blackwell Publishing

Mincer, J. (1958): Investment in human capital and personal income distribution. Journal of Political Economy 66 (August): 281-302.

Mincer, J. (1974): Schooling, Experience and Earnings. New York: Colombia University Press. 
Newmark, D. (1988): Employer Discriminatory Behaviour and the Estimation of Wage Behaviour, Journal of Human Resources, 23, 279-95

Oaxaca, R. L. (1973): Male-Female Wage Differentials in Urban Labour Market, International Economic Review, Vol. 14, No. 3, pp. 693-709

Oaxaca, R. L. and M. R. Ransom (1994): “On Discrimination and the Decomposition of Wage Differentials:, Journal of Econometrics, Vol. 61, pp. 5-21

Reimers, C. (1983): Labour Market Discrimination Against Hispanic and Black Men, The Review of Economics and Statistics, Vol. 65, 570-579

Robinson, P. (1999): Insecurity and the flexible workforce: measuring the ill defined, in Heery, E and J. Salmon edited The insecure workforce, Routledge UK

Rubin, B. A. (1995): Shifts in the Social Contract: Understanding Change in American Society, Pine Forge Press

Sachs, J., Varshney, A. Bajpai, N. (eds) (1999): India in the Era of Economic Reforms,. New Delhi: Oxford University Press

Seddighi, H. and K. Lawler (2000): Econometrics: A Practical Approach, Routledge UK

Sen, S. and Dasgupta, B. (2006), Labour Security in Organized Manufacturing Industries in India - A Parimary Survey based Analysis, paper presented at the International Conference on Development in Open Economies: Labour and Industries at Delhi during March 6-8, 2006.

Seth,k V.K. and S. C. Aggarwal (2004): The Economics of Labour Markets: Policy Regime Changes and the Progress of Labour Adjustment in the Organised Industry in India, Ane books

Silber, J. and M. Weber (1999): Labor Market Discrimination: Are There Significant Difference between the Various Decomposition Procedure, Applied Economics, Vol. 31, No. 3, pp. 359-365

Sivananthiran, A. and C. S. Venkata Ratnam (2004): Social Dialogue at Enterprise Level - Successful Experiences, ILO

Smith, D. M. (2002): Pay and productivity difference between male and female veterinarians, Industrial and Labor Relations Review, Vol. 55, No. 3

Smith, S. (2003): Labour Economics, Routledge (UK)

Standing, G. (1989): Global Feminisation through Flexible Labour, World Development, Vol. 17(7), pp. 1077-95

Standing, G. (1999): Global Labour Flexibility: Seeking Redistributive Justice, Macmillan Pres Ltd, London

Standing, G. (2002): Beyond the New Paternalism, Verso

Taylor, L. (1993): The Rocky Road to Reform: Adjustment, Income Distribution and Growth in Developing World, The MIT Press, Cambridge

Walance and Brady (2001): The Next Long Swing: Specialization, Technocratic Control, and the Restructuring of Work at the Turn of the Century, in I. Berg, A. 
L. Kalleberg (eds) Source Book of Labour Markets: Evolving Structures and Processes, Springer

World Bank (2000): Poverty and Policy in Latin America and the Caribbean, World Bank Publications 


\section{Appendix}

Figure 1: Contract worker as a percentage of total workers in Indian manufacturing industries

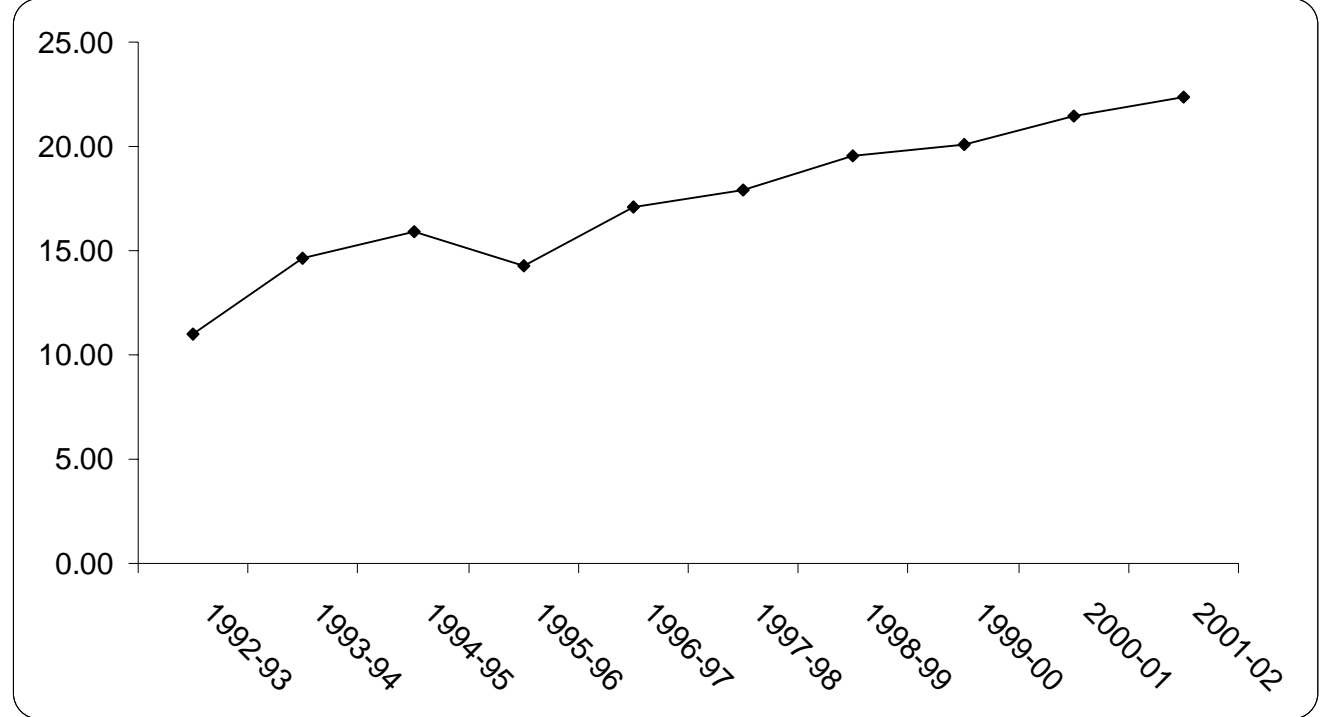

Figure 2: Share of contract worker of the total workforce (1992-2002)

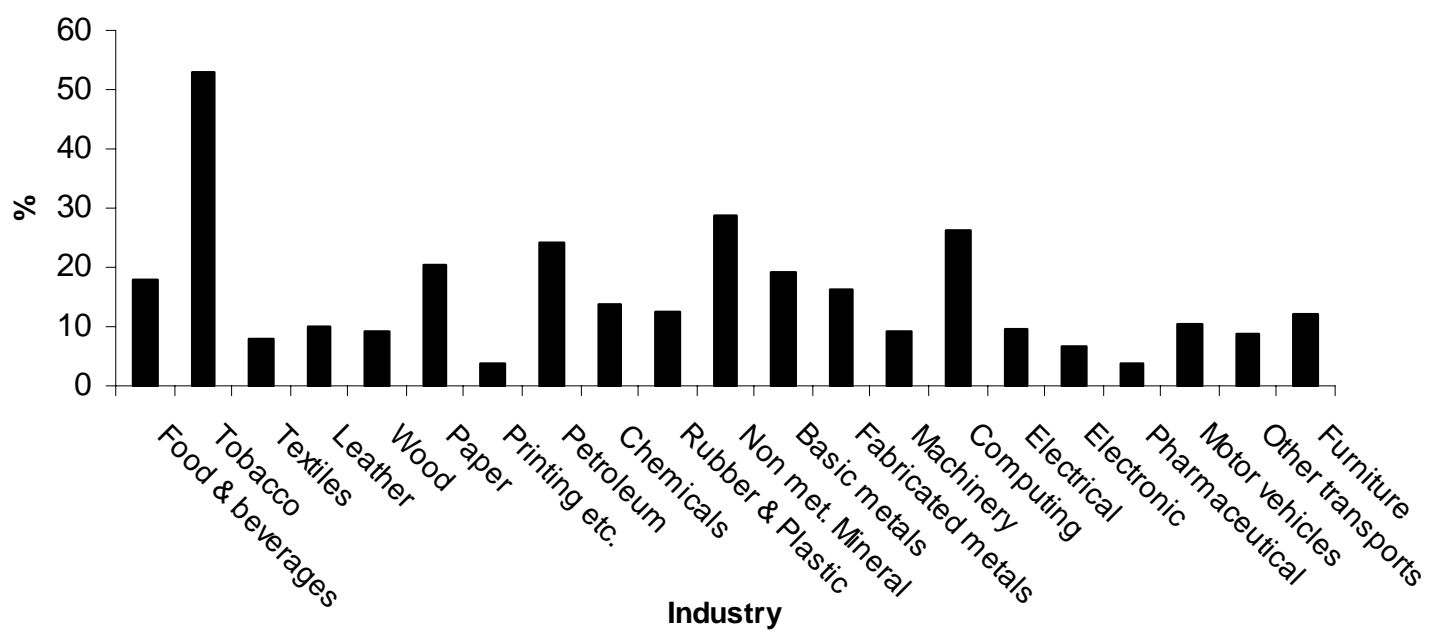


Table 1: Industry wise distribution of contract worker in manufacturing (in per cent)

\begin{tabular}{|c|c|c|c|}
\hline $\begin{array}{c}\text { Industry Name } \\
\text { \& Code }\end{array}$ & $\begin{array}{c}1992-98 \\
\text { to } \\
1997-98 \\
\end{array}$ & $\begin{array}{c}1997-98 \\
\text { to } \\
2002-03\end{array}$ & 2002-2003 \\
\hline Food \& beverages (15) & 15.92 & 21.40 & 18.41 \\
\hline Tobacco (16) & 46.30 & 61.98 & 53.43 \\
\hline Textiles (17) & 7.18 & 9.40 & 8.19 \\
\hline Leather (19) & 7.57 & 13.62 & 10.32 \\
\hline Wood (20) & 8.79 & 10.81 & 9.71 \\
\hline Paper (21) & 20.17 & 22.33 & 21.15 \\
\hline Printing etc. (22) & 2.79 & 6.10 & 4.30 \\
\hline Petroleum (23) & 15.62 & 25.18 & 19.97 \\
\hline Chemicals (24) & 14.21 & 20.65 & 17.14 \\
\hline Rubber \& Plastic (25) & 8.77 & 12.77 & 10.59 \\
\hline Non met. mineral (26) & 24.80 & 33.31 & 28.67 \\
\hline Basic metals (27) & 16.47 & 23.09 & 19.48 \\
\hline Fabricated metals (28) & 12.31 & 24.25 & 17.74 \\
\hline Machinery (29) & 8.22 & 11.60 & 9.75 \\
\hline Computing (30) & 19.64 & 33.21 & 25.81 \\
\hline Electrical (31) & 6.30 & 15.77 & 10.60 \\
\hline Electronic (32) & 5.57 & 9.06 & 7.16 \\
\hline Pharmaceutical (33) & 2.82 & 5.41 & 4.00 \\
\hline Motor vehicles (34) & 7.75 & 15.76 & 11.39 \\
\hline Other transports (35) & 4.50 & 15.79 & 9.63 \\
\hline Furniture (36) & 9.20 & 16.42 & 12.48 \\
\hline
\end{tabular}


Table 2: Description of independent variables used in the earning model

\begin{tabular}{|c|c|}
\hline Casual & Worker's type; takes the value of 1 if the worker is casual \\
\hline Income & Hourly earning of each worker (Rs.) \\
\hline Basic Education & Takes the value of 1 if the worker have basic education \\
\hline Secondary Education & Takes the value of 1 if the degree is secondary \\
\hline Higher Secondary & $\begin{array}{l}\text { Takes the value of } 1 \text { if the worker has passed higher secondary } \\
\text { education }\end{array}$ \\
\hline Graduate \& above & Takes the value of 1 if the degree is graduate and above \\
\hline Experience & Years involved in the present job \\
\hline Experience $^{2}$ & Square of tenure \\
\hline Skill & Takes the value of 1 if the worker have general skill of working \\
\hline Advanced Skill & Takes the value of 1 if the worker have got special training \\
\hline Migration & Takes the value of 1 if the worker is a migrant \\
\hline Union member & Takes the value of 1 if the worker is an union member \\
\hline Relation & 1 if the worker has good relationship with his supervisor \\
\hline SEZ & $\begin{array}{l}\text { Takes the value of } 1 \text { for special economic zone (SEZ) included } \\
\text { in our study }\end{array}$ \\
\hline Industry & $\begin{array}{l}\text { Takes the value of } 1 \text { for a group of major industries followed } \\
\text { two digit industry classification }\end{array}$ \\
\hline
\end{tabular}


Table 3: Percentage distribution of the respondents according to different categories of workers

\begin{tabular}{|c|c|c|c|}
\hline Characteristics & Permanent & Contract & Total \\
\hline All Workers & 49.2 & 50.8 & 100.0 \\
\hline \multicolumn{4}{|l|}{ Education: } \\
\hline Literate \& primary & 8.5 & 12.9 & 10.7 \\
\hline Basic education & 38.4 & 40.0 & 39.2 \\
\hline Secondary & 25.1 & 22.5 & 23.8 \\
\hline Higher secondary & 18.8 & 18.6 & 18.7 \\
\hline Graduate & 9.2 & 6.1 & 7.6 \\
\hline \multicolumn{4}{|l|}{ Experience: } \\
\hline Less than 2 years & 12.5 & 49.6 & 31.4 \\
\hline $3-5$ years & 22.5 & 35.7 & 29.2 \\
\hline $6-10$ years & 19.2 & 8.9 & 14.0 \\
\hline More than 10 years & 45.8 & 5.7 & 25.4 \\
\hline \multicolumn{4}{|l|}{ Skill: } \\
\hline Skilled worker & 83.0 & 76.8 & 79.9 \\
\hline Unskilled workers & 17.0 & 23.2 & 20.1 \\
\hline \multicolumn{4}{|l|}{ Advanced Skill: } \\
\hline Yes & 20.3 & 12.5 & 16.3 \\
\hline No & 79.7 & 87.5 & 83.7 \\
\hline \multicolumn{4}{|l|}{ Union Membership: } \\
\hline Union member & 50.6 & 39.6 & 45.0 \\
\hline Non member & 49.4 & 60.4 & 55.0 \\
\hline \multicolumn{4}{|l|}{ Migration: } \\
\hline Migrant & 47.2 & 46.1 & 46.6 \\
\hline Non-migrant & 52.8 & 53.9 & 53.4 \\
\hline \multicolumn{4}{|l|}{ Industry Location: } \\
\hline West Bengal & 57.2 & 56.1 & 56.6 \\
\hline Maharastra & 8.1 & 8.9 & 8.5 \\
\hline New Delhi & 21.4 & 12.5 & 16.9 \\
\hline Utter Predesh & 8.9 & 20.0 & 14.5 \\
\hline Haryana & 4.4 & 2.5 & 3.4 \\
\hline \multicolumn{4}{|l|}{ Special Economic Zone: } \\
\hline Other sectors & 90.8 & 87.5 & 10.9 \\
\hline SEZ & 9.2 & 12.5 & 89.1 \\
\hline \multicolumn{4}{|l|}{ Industry: } \\
\hline Food \& beverages (15) & 9.6 & 3.6 & 6.5 \\
\hline Textiles (17) & 4.4 & 7.9 & 6.2 \\
\hline Wearing apparel (18) & 8.1 & 12.1 & 10.2 \\
\hline Leather (19) & 3.3 & 2.1 & 2.7 \\
\hline Paper (21) & 2.2 & 3.6 & 2.9 \\
\hline Printing etc. (22) & 4.8 & 1.1 & 2.9 \\
\hline Chemicals (24) & 14.4 & 13.9 & 14.2 \\
\hline Rubber \& Plastic (25) & 8.1 & 16.8 & 12.5 \\
\hline Non met. mineral (26) & 2.2 & 1.4 & 1.8 \\
\hline Basic metals (27) & 10.3 & 4.3 & 7.3 \\
\hline Fabricated metals (28) & 1.1 & 3.2 & 2.2 \\
\hline Machinery (29) & 3 & 9.6 & 6.4 \\
\hline Electrical (31) & 13.3 & 10 & 11.6 \\
\hline Motor vehicles (34) & 6.3 & 1.1 & 3.6 \\
\hline Other transports (35) & 3.7 & 3.6 & 3.6 \\
\hline Furniture (36) & 5.2 & 5.7 & 5.4 \\
\hline Number of observations & 271 & 280 & 551 \\
\hline
\end{tabular}


Table 4: Wage differentials: Permanent and Casual Workers

\begin{tabular}{|c|c|c|c|}
\hline \multirow{2}{*}{ Characteristics } & \multicolumn{3}{|c|}{ Hourly wage rates (Rs.) } \\
\hline & Permanent & Contract & Total \\
\hline All Workers & 19.9 & 11.3 & 15.6 \\
\hline \multicolumn{4}{|l|}{ Education: } \\
\hline Literate \& primary & 18.3 & 9.9 & 13.2 \\
\hline Basic education & 17.4 & 10.6 & 13.9 \\
\hline Secondary & 20.2 & 12.1 & 16.3 \\
\hline Higher secondary & 22.5 & 13.0 & 17.7 \\
\hline Graduate & 26.1 & 11.1 & 20.0 \\
\hline \multicolumn{4}{|l|}{ Experience: } \\
\hline Less than 2 years & 17.5 & 11.6 & 12.8 \\
\hline $3-5$ years & 19.8 & 10.4 & 14.0 \\
\hline $6-10$ years & 17.5 & 12.7 & 16.0 \\
\hline More than 10 years & 21.6 & 11.8 & 20.5 \\
\hline \multicolumn{4}{|l|}{ Skill: } \\
\hline Skilled worker & 20.8 & 11.5 & 15.6 \\
\hline Unskilled workers & 19.8 & 11.3 & 15.3 \\
\hline \multicolumn{4}{|l|}{ Migration } \\
\hline Migrant & 17.9 & 12.2 & 15.1 \\
\hline Non-migrant & 21.7 & 10.6 & 16.0 \\
\hline \multicolumn{4}{|l|}{ Advanced Skill } \\
\hline Yes & 27.7 & 13.8 & 22.3 \\
\hline No & 18.0 & 11.0 & 14.2 \\
\hline \multicolumn{4}{|l|}{ Union Membership: } \\
\hline Union member & 21.3 & 11.6 & 17.0 \\
\hline Non member & 18.3 & 11.2 & 14.4 \\
\hline \multicolumn{4}{|l|}{ Industry Location: } \\
\hline Other sectors & 14.7 & 9.2 & 11.5 \\
\hline SEZ & 20.5 & 11.6 & 16.1 \\
\hline \multicolumn{4}{|l|}{ Industry: } \\
\hline Food \& beverages (15) & 22.0 & 10.0 & 18.7 \\
\hline Textiles (17) & 20.6 & 11.9 & 15.0 \\
\hline Wearing apparel (18) & 15.8 & 13.3 & 14.3 \\
\hline Leather (19) & 22.4 & 16.3 & 20.0 \\
\hline Paper (21) & 11.1 & 9.3 & 10.0 \\
\hline Printing etc. (22) & 15.2 & 16.3 & 15.4 \\
\hline Chemicals (24) & 19.5 & 8.6 & 14.0 \\
\hline Rubber \& Plastic (25) & 16.0 & 9.2 & 11.3 \\
\hline Non met. mineral (26) & 20.3 & 11.4 & 16.8 \\
\hline Basic metals (27) & 17.8 & 11.5 & 15.9 \\
\hline Fabricated metals (28) & 19.9 & 12.6 & 14.4 \\
\hline Machinery (29) & 28.5 & 11.4 & 15.3 \\
\hline Electrical (31) & 23.5 & 13.5 & 19.1 \\
\hline Motor vehicles (34) & 23.3 & 11.2 & 21.5 \\
\hline Other transports (35) & 22.3 & 12.6 & 17.5 \\
\hline Furniture (36) & 20.2 & 12.9 & 16.3 \\
\hline Number of observations & 271 & 280 & 551 \\
\hline
\end{tabular}

Note: Author's Calculation 
Table 5: Earning Equation of the Workers

(Dependent Variable: Log hourly earning)

\begin{tabular}{|c|c|}
\hline Explanatory variable & Coefficients \\
\hline Intercept & $\begin{array}{c}2.387^{*} \\
(30.682)\end{array}$ \\
\hline Casual (1) & $\begin{array}{c}-0.375^{*} \\
(-9.773)\end{array}$ \\
\hline \multicolumn{2}{|l|}{ Education (2) } \\
\hline Secondary & $\begin{array}{c}0.054^{* *} \\
(1.822)\end{array}$ \\
\hline HS & $\begin{array}{l}0.105^{*} \\
(2.454) \\
\end{array}$ \\
\hline Graduate \& above & $\begin{array}{l}0.262 * \\
(4.302)\end{array}$ \\
\hline Experience & $\begin{array}{c}0.025 \\
\left(4.411^{*}\right)\end{array}$ \\
\hline Experience squared $/ 10^{2}$ & $\begin{array}{c}-0.020 * \\
(-1.659)\end{array}$ \\
\hline Skill (3) & $\begin{array}{c}0.009 \\
(0.243)\end{array}$ \\
\hline Advanced Skill(4) & $\begin{array}{l}0.188^{*} \\
(3.931)\end{array}$ \\
\hline Migration (6) & $\begin{array}{c}-0.060^{* *} \\
(-1.855)\end{array}$ \\
\hline Union membership (7) & $\begin{array}{l}0.109 * \\
(3.307)\end{array}$ \\
\hline SEZ (8) & $\begin{array}{c}-0.144^{*} \\
(-2.555)\end{array}$ \\
\hline Industry (9) & Yes \\
\hline Area (11) & Yes \\
\hline Adjusted $\mathrm{R}^{2}$ & 0.569 \\
\hline $\mathrm{F}$ & 31.216 \\
\hline No. of observation & 551 \\
\hline
\end{tabular}

Note: Reference category, (1) Permanent; (2) Literate of primary education; (3) Below 3 years; (4) Unskilled; (5) No special training; (6) Non-migrant; (7) No union membership; (8) Other than SEZ area; (9) other than major industry group of the sample.

Coefficients of industry category and area are not reported to preserve space

* Statistically significant at the 0.01 level; ** at the 0.05 level of significance 
Table 6: Earning Equation: Permanent and casual workers

(Dependent Variable: Log hourly earning)

\begin{tabular}{|c|c|c|c|c|c|c|}
\hline \multirow{2}{*}{ Independent variable } & \multicolumn{3}{|c|}{ Permanent } & \multicolumn{3}{|c|}{ Casual } \\
\hline & Mean & $\beta_{P}$ & t-value & Mean & $\beta_{C}$ & t-value \\
\hline \multicolumn{7}{|l|}{ [Literate \& primary] } \\
\hline Secondary & $0.251^{* *}$ & 0.096 & 1.783 & 0.225 & 0.036 & 0.727 \\
\hline Higher secondary & $0.188^{*}$ & 0.174 & 2.837 & $0.186^{* *}$ & 0.064 & 1.117 \\
\hline Graduate \& above & $0.092 *$ & 0.341 & 4.023 & $0.061^{* *}$ & 0.144 & 1.669 \\
\hline Experience & $12.616^{*}$ & 0.018 & 6.085 & $3.752^{*}$ & 0.017 & 3.597 \\
\hline \multicolumn{7}{|l|}{ [Unskilled] } \\
\hline Skilled & 0.830 & 0.021 & 0.346 & 0.768 & 0.001 & 0.015 \\
\hline \multicolumn{7}{|l|}{ [No advanced skill] } \\
\hline Advanced Skill & $0.203^{*}$ & 0.312 & 4.821 & 0.125 & 0.036 & 0.543 \\
\hline \multicolumn{7}{|l|}{ [Non-migrant] } \\
\hline Migrant & $0.472 *$ & -0.108 & -1.985 & 0.461 & -0.048 & -0.884 \\
\hline \multicolumn{7}{|l|}{ [No union membership] } \\
\hline Union member & 0.506 & 0.013 & -0.210 & $0.396 *$ & 0.102 & 2.074 \\
\hline \multicolumn{7}{|l|}{ [Non Sez] } \\
\hline SEZ & $0.092^{*}$ & -0.264 & -3.078 & $0.125^{*}$ & -0.154 & -2.067 \\
\hline Constant & & 2.424 & 25.04 & & 2.157 & 26.33 \\
\hline Number of Observation & & 271 & & & 280 & \\
\hline F stat & & 10.08 & & & 10.24 & \\
\hline Adjusted R-square & & 0.425 & & & 0.422 & \\
\hline
\end{tabular}

Note: * Statistically significant at the 0.01 level; ** at the 0.05 level of significance Industry and regional figures are included to preserve space.

Omitted variables serving as reference are shown in the parentheses. 
Table 7: Decomposition of permanent-contract wage gap

\begin{tabular}{|l|c|c|c|}
\hline \multirow{2}{*}{ Decomposition } & \multicolumn{3}{|c|}{ Portion attributable to differences in } \\
\cline { 2 - 4 } & Total Gap & Characteristics & Discrimination \\
\hline \multirow{2}{*}{ Permanent weight } & 0.625 & 0.215 & 0.410 \\
& $(100)$ & $(34.38)$ & $(65.62)$ \\
\hline \multirow{2}{*}{ Contract weight } & 0.625 & 0.189 & 0.436 \\
& $(100)$ & $(30.21)$ & $(69.79)$ \\
\hline
\end{tabular}

Table 8: Decomposition of log monthly wage differences and its determinants

\begin{tabular}{|l|c|c|}
\hline \multirow{2}{*}{ Variable } & Permanent weight & Contract weight \\
\cline { 2 - 3 } & \multicolumn{2}{|c|}{ Attributable to differences in characteristics } \\
\cline { 2 - 3 } Education & 0.013 & 0.006 \\
& $(2.15)$ & $(0.88)$ \\
\hline \multirow{2}{*}{ Experience } & 0.160 & 0.151 \\
& $(25.53)$ & $(24.11)$ \\
\hline \multirow{2}{*}{ Skill } & 0.001 & 0.0001 \\
& $(0.21)$ & $90.01)$ \\
\hline \multirow{2}{*}{ Advanced skill } & 0.024 & 0.003 \\
& $(3.89)$ & $(0.45)$ \\
\hline \multirow{2}{*}{ Migration } & -0.001 & -0.001 \\
& $(-0.19)$ & $(-0.08)$ \\
\hline \multirow{2}{*}{ Union membership } & 0.001 & 0.011 \\
& $(0.23)$ & $(1.80)$ \\
\hline \multirow{2}{*}{ SEZ } & 0.009 & 0.005 \\
& $(1.39)$ & $(0.81)$ \\
\hline \multirow{2}{*}{ Industry characteristics } & 0.041 & 0.022 \\
\multirow{2}{*}{ Region } & $(6.53)$ & $(3.51)$ \\
& -0.034 & -0.008 \\
Total explained & $(-5.36)$ & $(-1.28)$ \\
\hline \multirow{2}{*}{ Total unexplained } & 0.215 & $(30.21)$ \\
\hline \multirow{2}{*}{ Total log wage difference } & $(34.38)$ & 0.436 \\
& 0.410 & $(69.79)$ \\
\hline
\end{tabular}

Note: Results are based on the regression result presented in Table 4. Figures in the parentheses denote the percentage of the total differentials explained. 
Table 9: Logit estimation of job insecurity

\begin{tabular}{|l|c|c|c|c|c|c|}
\hline \multirow{2}{*}{ Variable } & \multicolumn{2}{|c|}{ All Workers } & \multicolumn{2}{c|}{ Permanent } & \multicolumn{2}{c|}{ Contract } \\
\cline { 2 - 7 } & Coefficient & $\begin{array}{c}\text { Standard } \\
\text { Error }\end{array}$ & Coefficient & $\begin{array}{c}\text { Standard } \\
\text { Error }\end{array}$ & Coefficient & $\begin{array}{c}\text { Standard } \\
\text { Error }\end{array}$ \\
\hline Constant & $2.851^{*}$ & 0.579 & $3.340^{*}$ & 0.986 & $3.282^{*}$ & 0.965 \\
\hline Permanent worker & $0.824^{*}$ & 0.298 & & & & \\
\hline Education & $-0.054^{* *}$ & 0.042 & $0.081^{* *}$ & 0.074 & $-0.105^{*}$ & 0.058 \\
\hline Income & $-0.050^{*}$ & 0.019 & 0.006 & 0.024 & $-0.213^{*}$ & 0.047 \\
\hline Job duration & 0.016 & 0.016 & 0.013 & 0.021 & $0.058^{* *}$ & 0.040 \\
\hline Skill & $0.535^{*}$ & 0.286 & 0.304 & 0.470 & $0.867^{*}$ & 0.411 \\
\hline Advanced skill & $0.854^{*}$ & 0.329 & -0.035 & 0.489 & $1.822^{*}$ & 0.507 \\
\hline Union membership & $-1.594^{*}$ & 0.257 & $-1.822^{*}$ & 0.469 & $-1.157^{*}$ & 0.337 \\
\hline $\begin{array}{l}\text { Relation with } \\
\text { supervisor }\end{array}$ & $-2.190^{*}$ & 0.298 & $-3.723^{*}$ & 0.632 & $-1.013^{*}$ & 0.423 \\
\hline Migration & $-0.994^{*}$ & 0.235 & $-1.627^{*}$ & 0.523 & $-1.351^{*}$ & 0.333 \\
\hline-2 Log likelihood & 531.0 & & 218.67 & & 262.85 & \\
\hline Number of cases & 551 & & 271 & & 280 & \\
\hline
\end{tabular}

Notes: $1 .{ }^{*} 0.01<\mathrm{p}<-0.05,{ }^{* *} 0.05<\mathrm{p}<-0.10$ level of significance

2. The reference category for 'Permanent Worker' is 'Casual Worker, 'Unskilled' for 'Skill', 'No special training' for 'Special training', 'No union membership' for 'Union membership', 'Non migrant' for 'Migration' and 'Relation with supervisor' for 'Bad relationship with supervisor'. 